\title{
LA-UR-21-26460
}

Approved for public release; distribution is unlimited.

Title:

ANALYSIS OF ALTERNATIVE CORE DESIGNS FOR FISSION SURFACE POWER CAPABILITY DEMONSTRATION MISSION

Author(s): $\quad$ Dasari, Venkateswara Rao

Blood, Mikaela E.

Intended for: Report

Issued: 
Disclaimer:

Los Alamos National Laboratory, an affirmative action/equal opportunity employer, is operated by Triad National Security, LLC for the National Nuclear Security Administration of U.S. Department of Energy under contract 89233218CNA000001. By approving this article, the publisher recognizes that the U.S. Government retains nonexclusive, royalty-free license to publish or reproduce the published form of this contribution, or to allow others to do so, for U.S. Government purposes. Los Alamos National Laboratory requests that the publisher identify this article as work performed under the auspices of the U.S. Department of Energy. Los Alamos National Laboratory strongly supports academic freedom and a researcher's right to publish; as an institution, however, the Laboratory does not endorse the viewpoint of a publication or guarantee its technical correctness. 


\section{ANALYSIS OF ALTERNATIVE CORE DESIGNS FOR FISSION SURFACE POWER CAPABILITY DEMONSTRATION MISSION}

Los Alamos National Laboratory

DV Rao

Mikaela Blood

Version 1

June 2021 


\title{
ANALYSIS OF ALTERNATIVE CORE DESIGNS FOR FISSION SURFACE POWER CAPABILITY DEMONSTRATION MISSION
}

\author{
TABLE OF CONTENTS
}

\section{INTRODUCTION}

2. ALIGNMENT OF FSP WITH HERITAGE TECHNOLOGIES AND INDUSTRY INITIAVTIVES

3. REACTOR MODULE SYSTEMS, STRUCTURES AND COMPONENTS TECHNOLOGY READINESS

3.1. Nuclear Fuel Materials and Fabrication Readiness

3.2. Moderator Materials and Fabrication Readiness

3.3. Reflector materials and fabrication readiness

3.4. Shielding Materials and Fabrication Readiness

3.5. Structure materials and fabrication readiness

3.6. Control System Readiness

3.7. Heat Transfer Technology Readiness

3.8. Multi-Layer Insulation Technology readiness

4. REACTOR MODULE INTEGRATION, DEMONSTRATION, AND QUALIFICATION READINESS

4.1. Representative Reactor Classes for Achieving FSP Objectives

4.2. Reactor Core Mass Sensitivity to Reactor Class

4.3. Shielding Mass Sensitivity to Reactor Class

4.4. Non-Nuclear Technology Readiness Level Sensitivity to Reactor Class

4.5. Nuclear Technology Readiness Level Sensitivity to Reactor Class

5. PEER REVIEW FINDINGS

6. CONCLUSIONS

FIGURE 1. LAYOUT OF IMPORTANT COMPONENTS AND STRUCTURES IN A GENERICIZED FSP REACTOR

TABLE 1. TECHNICAL DESIGN REQUIREMENTS

TABLE 2. STMD GUIDELINES FOR FSP DEVELOPMENT

TABLE 3. READINESS LEVELS OF SELECTED FSP COMPONENTS AND MATERIALS

TABLE 4. IMPORTANT TRADE-OFFS BETWEEN ALTERNATIVE REACTOR CLASSES 


\section{ANALYSIS OF ALTERNATIVE CORE DESIGNS FOR FISSION SURFACE POWER CAPABILITY DEMONSTRATION MISSION}

\section{INTRODUCTION}

NASA's Space Technology Mission Directorate (STMD) intends to demonstrate a $10 \mathrm{kWe}$ fission surface power (FSP) system on the surface of the Moon as part of a Capability Demonstration Mission. STMD tasked a joint NASA-DOE team to 'outline an FSP reactor concept that can be readied for 2027 launch,' and serves 'as a pathfinder for future power modules for Mars.' Tables 1 and 2 respectively list FSP performance requirements and design guidance provided for the study ${ }^{1}$. DOE is the leading agency for the reactor module, reactor controls and radiation shielding, and shares joint responsibility for the overall FSP system. This report summarizes an analysis of alternative reactor classes and shielding configurations carried out by the DOE national laboratories. Representative reactor and shielding configurations were based on heritage and are in alignment with the industry initiatives. This report presents no recommendations on the appropriate choice of fuel or class of reactor that NASA should pursue. Instead the focus here is to provide a summary and findings of analyses carried out by DOE national laboratory personnel.

\section{ALIGNMENT OF FSP WITH HERITAGE TECHNOLOGIES AND INDUSTRY INITIAVTIVES}

This section explores how the proposed FSP Program could benefit from the heritage technologies and provide benefit to the U.S. nuclear microreactor industry.

Space nuclear power is a technical area that has garnered intense national and international interest. Not surprisingly, numerous designs were developed and disclosed by academy and industry over time. An early step of this study was to compile a list of heritage designs that have high technology readiness levels and of interest to U.S. microreactor and space nuclear power industry. Every effort was made to compile and factor in information related to industry reactor design and development ${ }^{2}$.

In 1965, the U.S. launched the first-ever nuclear reactor and an ion thruster to orbit the earth. The SNAP 10A reactor used $4.75 \mathrm{~kg}$ of ${ }^{235} \mathrm{U}$ in the form of highly enriched uranium-zirconium-hydride. Hydride fuel was formed into long rods, clad in Hastelloy and assembled into a bundle to form the nuclear core that was surrounded by metallic beryllium reflector; rotating control drums housed in

\footnotetext{
${ }^{1}$ STMD guidelines are documented in "Preliminary Design Study of Lunar Surface Fission Power System with Extensibility to Future Mars Operation."

${ }^{2}$ Industry interests in the microreactor technologies were documented in the Nuclear Energy Institute report "Cost Competitiveness of Microreactors for Remote Area Markets" (April 2019), and industry discussions with NASA HQ and NASA Marshall.
} 
the reflector were used for startup and reactivity control. Hastelloy was used for all structural elements and liquid sodium-potassium eutectic was circulated through the core reaching an exit temperature of $540^{\circ} \mathrm{C}$. Estimated fuel temperatures varied between $600-620^{\circ} \mathrm{C}$ depending on location and power levels. The unshielded reactor weighed approximately $300 \mathrm{~kg}$ with a design thermal power of $34 \mathrm{~kW}$ ( $0.5 \mathrm{~kW}$ of electrical power from thermoelectric converters) for up to one year. SNAP 10A was unable to solve hydrogen leakage or redistribution problems and it was predicted to lose about 20 cents $(160 \mathrm{pcm})$ of reactivity during its design life of one year; burnable poison $\left(\mathrm{Sm}_{2} \mathrm{O}_{3}\right)$ was used to compensate for hydrogen loss. Active control was required for about a week, and thereafter the system relied on strong inherent reactivity feedback. It operated successfully for 43 days in orbit and was shut down due to a non-nuclear failure. The ground qualification unit was run in parallel for 390 days at the design power $(35 \mathrm{kWt})$ followed by 30 days at $150 \%$ of design power $(45 \mathrm{kWt})$. The ground unit was shut down approximately a year after the SNAP 10 A flight unit was shut down in orbit.

Starting in 1967, Upravlyaemy Sputnik Aktivnyy (US-A) of the Former Soviet Union launched 33 reactors to power the Radar Ocean Reconnaissance Satellites (RORSAT). Of these, 31 were fastspectrum reactors commonly known as Buk (BES-5) reactors, that used between 30 and $40 \mathrm{~kg}$ of uranium molybdenum alloy fuel rods that are $>90 \%$-enriched in ${ }^{235} \mathrm{U}$. BUK reactors weighed nearly $400 \mathrm{~kg}$ including directional neutron shielding and generated $100 \mathrm{~kW}$ of thermal power that was converted into $1.3 \mathrm{~kW}$ of electric power. The use of thermoelectric converters and electromagnetic pumps resulted in a large balance of plant foot print. Accidental reentry of Buk reactor over Canada, among other factors, exposed vulnerability of launching large amount of highly attractive fuel into orbit. Toward the end of US-A program in 1988, designs had migrated toward Thermionic Experiment with Conversion in Active Zone (TOPAZ) which used ceramic nuclear fuel $\left(\mathrm{UO}_{2}\right)$ embedded with thermionic converters and moderated by $\mathrm{ZrH}_{1.85}$. The interior of the fuel operated between 1200 and $1400{ }^{\circ} \mathrm{C}$ to produce $5 \mathrm{~kW}$ of electric power. The fuel exterior was cooled by flowing liquid metal and was thermally separated from the moderator by a thin layer of alumina $\left(\mathrm{Al}_{2} \mathrm{O}_{3}\right)$. Each TOPAZ reactor contained approximately $10 \mathrm{~kg}$ of uranium enriched to $>$ $90 \%$ in ${ }^{235}$ U. Details on TOPAZ-I are limited, but the TOPAZ-II model was exhibited at University of New Mexico scientific symposium in 1991. Subsequently, the U.S. purchased six TOPAZ-II reactors - without nuclear fuel - for testing and evaluation of in-core thermionic converters. The testing program was ultimately cancelled in 1993 by which time significant data were accumulated establishing that

- a delta-phase hydride moderator can be very effective in retaining hydrogen if thermally isolated from the fuel, and sufficiently cooled to minimize thermal gradient; and

- the in-core thermionic power conversion system is unlikely to achieve efficiencies higher than $5-10 \%$ and the resulting $10-20 \mathrm{kWe}$ core is likely to weigh between 2000 and 4000 $\mathrm{kg}$ depending on uranium enrichment and level of moderation.

Since the 1980's, several attempts have been made to restart space nuclear reactor development in the U.S. (e.g., Space Reactor Prototype, SP-100, and Jupiter Icy Moon Orbiter, JIMO). All of them were at relatively higher power levels which required larger reactor cores operating at higher temperatures compared with SNAP. None of them were launched but in the process generated valuable insights and experimental data, including feasibility of using dynamic power conversion systems and uranium nitride fuel. Overall, heritage design analyses provided following insights: 
- The simplest core configuration - for example, a solid cylindrical core made of monolithic fuel or clad fuel rods (and moderator if used) surrounded by a Be reflector - will be sufficient at the thermal power levels of present interest (see Table 1).

- A simple control system is sufficient to operate compact reactor cores of the size expected for FSP. Except for occasional control rod adjustments to compensate for temperature drift due to hydrogen loss, burn up or unanticipated thermal losses, system self-regulates to follow electric load demand.

- Both fast-spectrum and thermal spectrum reactors can perform at the power levels and operating temperatures of interest to FSP. Fast-spectrum reactors are inherently simpler, but moderated designs are relatively lighter ${ }^{3}$.

Microreactor companies are attempting to build on technology advancements made as part of the space program to develop reactors in the 1-10 MWe range to meet the energy needs of remote communities and U.S. Department of Defense (DoD) bases. DOE's Office of Nuclear Energy (DOE-NE) and the Nuclear Energy Institute (NEI) have independently organized workshops and requests for information to gather industry interests. This list was augmented by industry input to NASA's nuclear thermal propulsion (NTP) program and ARPA-E workshop. Information from these sources was reclassified as applicable to FSP as follows:

- Two companies have early stage designs for space reactors in the 1-10 kWe range. Both of them used High Assay Low Enriched Uranium (HALEU) metal fuel moderated by high temperature hydrides and heat pipes for heat transport. These designs are amenable for use with either Stirling or Brayton power conversion systems.

- The lowest power range for commercial microreactors is $250 \mathrm{kWe}$; however, most are planned for a 2-20 MWe range. Brayton power conversion is the overwhelming choice for power conversion in this power range. HALEU is the baseline fuel enrichment while some of the variabilities in fuel forms can be summarized as follows:

- Fuel forms varied from metallic fuels (U9Mo and U10Zr), Uranium Nitride (UN) to AGR TRISO (the latter being most common among those proposed for use at the DoD facilities).

- Two of the early movers opted for HALEU metal fuel fast reactors cooled by heat pipes. One of these designs is in discussions with NRC. One other company is exploring use of 3-D printed, $\mathrm{UO}_{2}$ fueled, fast-spectrum gas cooled reactor (GFR).

- Established nuclear companies and startups alike have plans to develop AGR TRISO fueled moderated core designs in the 2-20 MWe range. At least three of them plan to use heat pipes, while others proposed direct gas cooling.

Comparison of industry designs with the heritage designs provides following insights:

\footnotetext{
${ }^{3}$ A DOE-funded effort (1992-1994) by the US industry and DOE national laboratories explored moderated designs with various enrichment levels for meeting US Air Force space power needs in the 5- to 40-kWe range. In general, moderated HEU designs were shown to be $25-35 \%$ lighter than their fast-spectrum equivalent. At HALEU enrichment, moderated designs were significantly lighter with a third of the weight of its fast-spectrum equivalent. A moderated core using HALEU enrichment is about 50\% heavier than a HEU fueled fast-spectrum reactor.
} 
- The Industry's reactor designs, fuel choices and their power conversion technologies are focused on economically viable modularized reactors in the 2-50 MWe range; they are fundamentally different from reactor designs suitable for space power where the foci are size, weight and control simplicity. On the other hand, the industry's microreactor research and development efforts - especially efforts related to engineering and fabrication of specialized components such as fuel blocks, moderators, reflectors, shields, power conversion, heat pipes and control systems - align well with FSP needs. Thus, FSP program might be of benefit to the industry and also benefit from procuring industry developed components, systems and structures.

- Heritage reactor designs - but not the fuels, materials or power conversion systems used in them - offer proven alternates for $\mathrm{FSP}^{4}$. They fall into two major classes: fast and moderated-spectrum reactors. Fast-spectrum reactors can be constructed of either HEU or Low Enriched Uranium (LEU). Variants within the moderated reactors include homogeneous type and segmented moderator type. In the homogeneous moderated reactors, such as SNAP $10 \mathrm{~A}$, the fuel and the moderator are in thermal and neutronic equilibrium; therefore, they need moderators that are stable at high operating temperatures of FSP. To avoid this limitation, NERVA, RamJet and TOPAZ designs, thermally isolated the moderator from the fuel such that the moderator is in equilibrium with the fuel neutronically but not thermally. These segmented moderator designs allow for high temperature process heat without concerns related to hydride stability. Many of the U.S. commercial vendors are leveraging these design features for use in conjunction with AGR TRISO fuel. Each of these four classes are further elaborated and contrasted in Section 4.

\section{REACTOR MODULE SYSTEMS, STRUCTURES AND COMPONENTS TECHNOLOGY READINESS}

Drawing from heritage, a simple space reactor design (that could serve as a starting point for FSP) consists of:

- an inner cylindrical core made of nuclear fuel (and moderator, if thermal spectrum) with openings for the shutdown rod and coolant passages;

- a neutron reflector, a neutron shield and a gamma shield - all surrounded successively by layers of thermal insulation;

- a control rod-drive that moves the shutdown rod in and out of the core (or rotates control drums positioned around the core) de facto serving as a thermostat;

- heat pipes (or gas flow) that transport heat from the core to the PCI; and

- a robust support structure that holds the system together against launch and landing loads.

Figure 1 is an example of a genericized reactor that illustrates the layers discussed above and served as the basis (or 'point-design') for the mass estimate ranges presented below. This section reviews technology readiness of the individual components with a particular focus on alignment

\footnotetext{
${ }^{4}$ At the FSP operating power, expected burnup and thermal gradients are minimal. As a result such reactors do not require special design features common to larger microreactors. Modern fuels, materials and simulation tools simplify fabrication and qualification approaches
} 
with the industry interests. Table 3 provides a summary of technology, nuclear and manufacturing readiness levels per standard NASA and DOE numerical rankings.

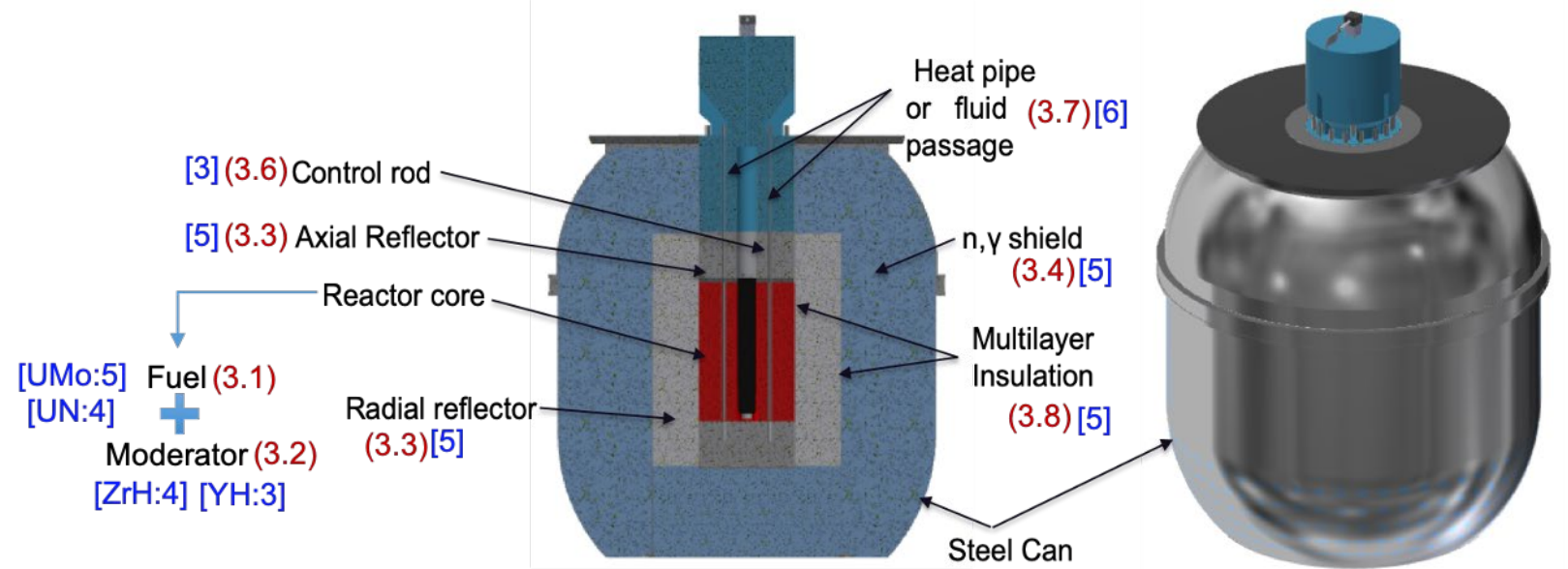

(x) Component ID and Section \# of the report

(3.5) [6]

[x] Technology Readiness Level

Figure 1. Layout of important components and structures in a genericized FSP reactor.

\subsection{Nuclear Fuel Materials and Fabrication Readiness}

Current U.S. commercial nuclear fuel infrastructure is primarily configured to support reactorgrade light water reactor fuels whereas DOE national laboratories operate facilities to produce specialty fuels. However, driven by interests of the accident tolerant fuel vendors, the microreactor vendors and the RERTR and VTR program needs, nuclear fuel manufacturing infrastructure is expanding around three fuel types: metallic (U10Zr or U10Mo), coated ceramics (UN, UC or $\mathrm{UO}_{2}$ ) and AGR TRISO. Based on a recent survey, HALEU metallic and traditional ceramic fuels have relatively high manufacturing readiness levels $(\mathrm{MRL} \geq 6)$ to meet FSP needs which are estimated to be $10-100 \mathrm{~kg}$ per year production rate depending on the level of enrichment. Uranium zirconium hydride fuel can be procured from TRIGA suppliers (MRL 5), but will likely have to be requalified for FSP temperature and hydrogen loading conditions. AGR TRISO manufacturing infrastructure is being reestablished to meet DoD microreactors needs and could be able to support 2027 FSP launch (assessed MRL of 3-4); however, the fuel will likely have to be extensively redesigned (larger kernels and denser packing) and re-qualified for $\mathrm{FSP}^{5}$.

Among the four fuel forms, uranium molybdenum alloy has the following advantages:

- Because of its high uranium density, uranium molybdenum alloy fuel results in the smallest core irrespective of fuel enrichment or reactor class (fast vs moderated).

\footnotetext{
${ }^{5}$ AGR TRISO fuel can be used in FSP but with severe impacts on reactor weight. At low power levels, reactor weight is 'criticality limited,' that is, its weight is approximately same as the minimum amount of fuel (and moderator mixture) required to achieve criticality. Two factors that most effect radius and weight of a criticality-limited core are: fissile material density (number of ${ }^{235} \mathrm{U}$ atom/cc) and fuel-to-moderator ratio. Use of low-density fuels such as AGR TRISO compacts - with or without moderators - increases reactor size and weight by a factor of between 2 and 8 depending on core configuration. This impact is further exacerbated when combined with shielding whose weight increases proportional to the square of the core radius. To overcome these drawbacks, AGR TRISO fuel system will have to be completely overhauled and requalified before it could be used in this application.
} 
- FSP design temperature $\left(700-800^{\circ} \mathrm{C}\right)$ is within the established operational limits of this alloy. Non-nuclear thermal creep testing might be needed to confirm performance over 15 years; which is well within the capabilities of numerous commercial companies.

- Uranium molybdenum alloy was qualified for use in both thermal and fast-spectrum reactors at the FSP burnup levels; if necessary, confirmatory Advanced Test Reactor (ATR) irradiation may be performed with no major impact on FSP schedule

- Finally, both DOE and a commercial vendor possess infrastructure for fabricating uranium molybdenum parts at HALEU and HEU enrichments.

Other fuels have the following limitations:

- UN fuel possesses necessary thermal and mechanical properties; it is qualified for operation at the FSP operating conditions and estimated 15-year burnup levels. Sensitivity analyses have shown that UN-fueled cores can be double the size of metallic fuel cores in the case of fast-spectrum designs; in thermal designs UN is competitive with U8Mo but still heavier. Currently, only national laboratories are capable of fabricating HALEU UN; a commercial ATF vendor has plans to fabricate UN based accident tolerant fuels.

- At a given enrichment level, uranium zirconium hydride-fueled cores are likely to be more compact than fast-spectrum cores. UZrH also has high TRL, but it does not support the required operational temperature ${ }^{6}$.

- AGR TRISO fuel compacts unequivocally resulted in large cores exceeding weight margins irrespective of whether a moderator is used. Redesigned AGR TRISO fuel (e.g., much larger kernels and higher packing ratio) become somewhat competitive but are still much heavier when shielding is factored in. Considerable development effort would be involved in tailoring and qualifying TRISO fuel for FSP use.

In conclusion, several qualified fuels exist to support a 2027 FSP launch. Among them, uranium molybdenum alloy and UN have nuclear, thermal and mechanical properties beneficial to FSP. Both fuels have high technology, nuclear, and manufacturing readiness levels, but HALEU UMo has a higher commercial manufacturing readiness level compared to HALEU UN. AGR TRISO compacts - a popular choice for terrestrial applications - are unlikely to yield competitive FSP reactor designs because of its low uranium fissile atom density. Although redesigned TRISO compacts with higher enrichment may meet FSP weight requirements, they would have to be requalified for this space applications and will face considerable development and schedule challenges. Use of UZrH fuel can yield compact cores, but it would require a lower operating temperature; associated complications are likely to over shadow any of its benefits.

\subsection{Moderator Materials and Fabrication Readiness}

A moderating material slows down neutrons which results in higher fission cross-section which in turn reduces the amount of fissile material required to achieve criticality. Hydrogenous materials are the most effective moderators; among them high temperature metal hydrides are most relevant

\footnotetext{
${ }^{6}$ Research data compiled since SNAP $10 \mathrm{~A}$ as well as ongoing DOE research clearly establishes that uranium zirconium hydride fuel is not stable at $700-800{ }^{\circ} \mathrm{C}$ of present interest. While hydrogen loss is controllable, its redistribution during operation is difficult to control.
} 
to FSP operating conditions. For example, a hydride moderated HALEU fueled core can be only marginally heavier than an HEU unmoderated core; alternately, a moderated HALEU core weighs half of its fast-spectrum equivalent. Driven by these superior fuel utilization considerations, current commercial interest into moderators extends to four metal hydrides: zirconium hydride, yttrium hydride $(\mathrm{YH})$, calcium hydride and lithium hydride. But hydrides also present several technology challenges, important among them is hydrogen loss at high temperature. At least three major U.S. nuclear companies are establishing infrastructure for research and fabrication of hydrides, including development and qualification of hydrogen barrier coatings. In addition, DOE$\mathrm{NE}$ is sponsoring research into nuclear qualification of the aforementioned hydride moderators which includes ATR irradiation data and criticality testing. Readiness levels of the four moderators for application to FSP are as follows:

- Zirconium hydride is most widely researched and used moderator with a TRL of 5. Recent emphasis has been on $\mathrm{ZrH}_{1.65}$ (delta-phase) with an effective hydrogen atom density between $5.5-6 \times 10^{22} \mathrm{~g} / \mathrm{cc}$. It undergoes slight swelling when subjected to high neutron fluxes, but otherwise is relatively stable below $500^{\circ} \mathrm{C}$ both in terms of hydrogen retention and phase-stability ( $\delta$ to $\varepsilon$ transition). Above $600^{\circ} \mathrm{C}, \mathrm{ZrH}_{1.65}$ requires special features to contain hydrogen; development and qualification of such technologies is feasible but challenging within 2027 launch schedule. The easiest route to industry-scale production of $\mathrm{ZrH}$ involves mass hydriding of pre-fabricated zirconium parts or pellets which is well within the capability of the nuclear industry and thus needs minimal additional development.

- Yttrium hydride is the most stable high temperature hydride extending operability up to $900^{\circ} \mathrm{C}$ and possessing a TRL of 4 . It was first used as a moderator as part of nuclear aircraft project and then in DOE's fast flux test reactor. In the latter case, $\mathrm{YH}_{1.85}$ was used continuously for 140 equivalent full power days at $300 \mathrm{MW}$ without any observed failure. Yttrium hydride does have neutron data gaps and DOE's Microreactor Program is actively pursuing a test program to obtain the necessary data. In particular, microscopic nuclear cross-sectional data measurements are underway at Oak Ridge National Laboratory (ORNL) and Los Alamos National Laboratory, and a criticality benchmark test is scheduled to validate neutronic codes later this fiscal year. Finally, samples of YH are also being readied for irradiation testing in ORNL's high-flux test reactor and INL's ATR later this fiscal year. At least two private companies are establishing capabilities for $\mathrm{YH}$ fabrication at-scale. Thus, YH is a feasible alternate for FSP.

- Lithium hydride $\left({ }^{6} \mathrm{LiH}\right)$ is in wide use as neutron shield. A major drawback of using ${ }^{7} \mathrm{LiH}$ as a moderator is that at temperatures above $200^{\circ} \mathrm{C}$, unhydrided lithium exists as liquidus requiring a honeycomb like metallic support structure which complicates its neutronic performance. Also, no experiments or demonstrations are underway to enhance TRL of ${ }^{7} \mathrm{LiH}$ at the temperatures of present interest and thus not a viable candidate for FSP; however, future moderated reactor designs could benefit considerably from this moderator.

- Calcium hydride is in very early stages of development with limited R\&D. Unless focused R\&D strategy is undertaken it is unlikely to be ready to support FSP 2027 launch.

It is concluded that zirconium hydride is most technologically mature and neutronically superior if the moderator temperature is $\leq 500{ }^{\circ} \mathrm{C}$; above that temperature, either $\mathrm{YH}$ or a compound of yttrium-zirconium hydride would be required. Both of these high temperature hydrides are of 
current interest to the microreactor vendors and proven fabrication routes exist for industry-scale fabrication of these hydrides. Both $\mathrm{ZrH}$ and $\mathrm{YH}$ parts are likely to be ready for procurement either from the industry or the national laboratories to support a FSP system 2027 launch.

\subsection{Reflector materials and fabrication readiness}

The two most widely used reflector materials are beryllium and beryllium oxide; all heritage reactors used $\mathrm{Be}$ owing to its lower density. $\mathrm{Be}$ and $\mathrm{BeO}$ parts are routinely procured by U.S. DOE national laboratories for use in test reactors and other systems. Two U.S. commercial vendors possess isotopically pure beryllium stock and have technology and manufacturing readiness levels to fabricate $\mathrm{Be}$ or $\mathrm{BeO}$ reflectors for FSP.

\subsection{Shielding Materials and Fabrication Readiness}

Shielding design methods, materials and fabrication have very high readiness levels. Pucks of ${ }^{6} \mathrm{LiH}$ housed in a steel structure, such as in SNAP $10 \mathrm{~A}$, are still widely used as neutron shield by other federal reactor programs. As required, the $\mathrm{LiH}$ shield is lined with either depleted uranium and/or tungsten. Commercial vendors and national laboratories possess design, fabrication, testing and qualification infrastructure for fabricating neutron and gamma shields to support a 2027 FSP system launch. Some non-nuclear engineering development effort would be necessary to design the structure.

\subsection{Structure materials and fabrication readiness}

High temperature alloys (such as Haynes 230, Hastealloy-N, Inconel and TZM) are required to support the reactor system withstand launch and landing loads. Commercial vendors and national laboratories possess fabrication, testing and qualification infrastructure to support a 2027 FSP system launch.

\subsection{Control System Readiness}

Heritage systems (SNAP, BUK, TOPAZ) used control drums for core startup and for regulating temperature drift - whether temperature drift is due to hydrogen kinetics or due to unanticipated excessive thermal loss. A drum-based control system is preferable if stored excessive reactivity is large and reactor core possesses inherent non-uniformities; otherwise a central control rod is sufficient. Both technologies are well within the technology capability of U.S. nuclear vendors who routinely supply such parts to U.S. nuclear industry and test reactor community. Commercial vendors and national laboratories possess fabrication, testing and qualification infrastructure for fabrication of control systems to support a 2027 FSP system launch.

\subsection{Heat Transfer Technology Readiness}

At FSP temperature and power levels three choices exist for heat removal: liquid metal circulated by electromagnetic pumps, alkali heat pipes and helium circulated by a either a dedicated "fan" or 
a compressor (if Brayton Power Conversion System is used). Alkali metal heat pipes possess the highest TRL and MRL, besides being the lightest and most flexible option. Alkali metal heat pipes could be procured from the industry. Two U.S. specialty vendors possess infrastructure to develop and qualify Brayton PCS and compressors, but neither have qualified units at this power/flow level. At higher power levels (150-250 kWt) direct cycle Brayton could be advantageous. No credible designs or products exist for liquid metal pumps ${ }^{7}$.

\subsection{Multi-Layer Insulation Technology readiness}

Multi-Layer Insulations (MLI) are widely used in the space applications including space nuclear designs. For FSP systems, MLI serves a critical role by limiting heat losses from the plant. General purpose heat source (GPHS) program previously developed and qualified an MLI technology based on molybdenum foils packed with low density 'astroquartz' fibers. Even more efficient technologies are now available for the temperature range of present interest (for example, recently, Jet Propulsion Laboratory unveiled an aerogel based MLI technology). Commercial vendors and NASA laboratories possess fabrication, testing and qualification infrastructure for fabrication of MLI to support a 2027 FSP system launch.

\section{REACTOR MODULE INTEGRATION, DEMONSTRATION, AND QUALIFICATION READINESS}

This section addresses integration, testing and acceptance of the reactor system as a whole and the impact that reactor class, or type, or alternate would have on the integration tasks and STMD performance criteria. Validated systems engineering and simulation (computational) tools have a vital role; their availability is briefly discussed under nuclear technology readiness section.

\subsection{Representative Reactor Classes for Achieving FSP Objectives}

Heritage points to two major classes of reactors: fast-spectrum and thermal-spectrum (or moderated) reactors. At power and burnup levels of relevance to FSP, fast-spectrum reactors are simple neutronically and have inherent ability to load follow. A fast-spectrum reactor can be based on HEU fuel, HEU-Fast, which is analogous to Soviet era BUK reactor, or based on HALEU fuel, or LEU-Fast, which aligns with design interest of two U.S. vendors.

Moderators could be used to either lower the quantity of HEU to below Category-I quantity as was done in the SNAP program, or to lower the LEU fueled reactor weight to fit within FSP weight requirements. FSP program interest is the latter, that is, to examine if an HALEU-fueled reactor that is in the same weight range as HEU-Fast could be readied to support a 2027 launch. Two subclasses are possible within the moderated LEU class. In the first subclass, a moderator is used in close proximity to fuel to form a neutronically and thermally homogeneous core similar to SNAP. This LEU-YH type reactor is the most compact moderated reactor option, requires least

\footnotetext{
${ }^{7}$ Heritage designs used liquid metal electro-magnetic pumps which at this power level are heavy, not efficient and consume between 2-5 KWe. No U.S. vendor possesses high TRL EM pumps that can support 2027 launch
} 
amount of fuel and performs similar to SNAP ${ }^{8}$. It also aligns with a U.S. vendor kW-class design. Because it uses $\mathrm{YH}$ which has lower TRL and thus carries forward higher risk. Final class is formulated to explore options for using higher TRL moderator $\mathrm{ZrH}_{1.65}$ within its operating envelope. This objective is achieved by using a thick multi-layer insulation to thermally isolate moderator from the cylindrical fuel shells embedded within the moderator. In this option, fuel cylinders operate at high temperature to meet power conversion system needs while the moderator is kept at a relatively low temperature of $400-500{ }^{\circ} \mathrm{C}$ to minimize potential for hydrogen loss or hydrogen redistribution over its 15 -year life. This option, LEU-ZrH, is neutronically analogous to TOPAZ and NERVA reactor designs and several U.S. vendors are exploring these design features for terrestrial use. This option possesses higher nuclear readiness level compared with LEU-YH, and rapid technology maturation is possible through non-nuclear testing (In fact, a single non-nuclear test could bring down most of the design uncertainties associated with this design). Finally, multi-layer insulation plays an important role in this design.

None of these reactor options should be considered as mature, but only as possible alternates for assessing their feasibility and relative advantages which are summarized in Table 4 and discussed in the following sections. As previously discussed, most of the non-nuclear parts could be procured directly from qualified vendors and fuel either from specific nuclear vendors or the DOE national laboratories. Computational tools and expertise necessary to design and assemble these two classes of reactors are present both at the industry and the national laboratories. DOE operates facilities required for assembling, testing and qualifying the integrated system - however, hardware and authorization basis modifications may be needed if a long-term reactor demonstration is needed to support flight readiness determinations.

\subsection{Reactor Core Mass Sensitivity to Reactor Class}

One of the STMD tasks calls for a "mass sensitivity analysis relative to the $2000 \mathrm{~kg}$ mass target, comparing HEU vs LEU reactor fuel over the 7-10 kWe power range of interest." Although choice of fuel, moderator and shield materials have the highest impact on mass, design features that enhance safety and fault-tolerance also contribute significantly to the overall mass. With this in mind, four alternate designs were matured to a level-of-fidelity sufficient to draw insights related to performance limits and their impact on system mass. Industry standard CAD software was used for authoring the geometries and for configuration control. Reactor cores were designed to withstand both frequent and rare off-normal events. Fully coupled multi-physics analyses, using industry standard and NEAMS tools, examined neutronic, thermal and mechanical performance of each assembly design including its ability to withstand extreme heat pipe failures (such as simultaneous failure of three adjacent heat pipes) and power conversion transients such as loss of complete heat removal over extended periods. Temperature and power density limits were selected to minimize thermal stresses during postulated off-normal operating conditions and specific mass estimates were directly obtained from the CAD models. Similarly, fuel-to-moderator volume ratios were selected to assure negative reactivity feedback $(\sim-1 \mathrm{pcm} / \mathrm{K})$ at operating conditions. Reactor cores were designed to remain sub-critical when water submerged. Specific mass estimates were directly obtained from the CAD models which are discussed below.

\footnotetext{
${ }^{8}$ Fundamental features of LEU-YH are: (a) it uses YH to support higher FSP operating temperatures; and (b) because uranium is not soluable in yttrium, fuel and moderator are fabricated separately and assembled with a thin buffer layer separating them; and (c) heat pipes are used instead of EM pump.
} 
- Estimates for HEU-Fast weight varied between $240-300 \mathrm{~kg}$. Of this, $35-40 \mathrm{~kg}$ was the mass of the fuel (93\% enriched HEU U8Mo alloy), $135-180 \mathrm{~kg}$ was the neutron reflector, and $10-20 \mathrm{~kg}$ was the control drive. Structural elements and heat pipes took up the remaining $50 \mathrm{~kg}$. Use of $\mathrm{Be}$ (instead of $\mathrm{BeO}$ ) and the use of neutronically efficient steels lowered the weight to about $240 \mathrm{~kg}$; on the other hand, use of thicker structural elements exclusively made of high temperature (nickel and/or tungsten bearing) steels pushed the weight to $300 \mathrm{~kg}$.

- LEU-Fast weight was estimated to vary between $850-1050 \mathrm{~kg}$ depending exclusively on the choice of materials used for the reflector and the structural support. Of this weight, LEU fuel and reflector account for $800 \mathrm{~kg}$.

- Moderated reactor weight estimates ranged between 280 and $350 \mathrm{~kg}$, slightly higher than HEU-Fast but significantly lighter than LEU-Fast. Of this, approximately $120-175 \mathrm{~kg}$ is HALEU U8Mo alloy and another $140 \mathrm{~kg}$ or so is the reflector.

Size and weight estimates provided here are accurate only over a range. Among the four classes HEU-fast design will always be the lightest and the most compact reactor core at FSP power and life-time. LEU moderated designs are likely to be $15 \%$ - 25\% heavier than HEU-Fast. LEU-Fast is unlikely to meet STMD weight requirements when combined with shielding and PCS. These findings are similar to those documented in the 1994 DOE study 9 .

\subsection{Shielding Mass Sensitivity to Reactor Class}

The purpose of the FSP shield is to limit dose at four locations, namely,

- a few meters away from the reactor, where Stirling engines and generators with mechanical parts are located;

- $10 \mathrm{~m}$ away, where reactor and PCS command and control systems containing hardened electronics are located;

- $100 \mathrm{~m}$ away, where power electronics, mission sensors and power outlet is located; and

- $1000 \mathrm{~m}$ away, where human habitat is envisioned to be located.

A series of studies was carried out to obtain a reasonable range for FSP shield weight. These studies commenced with DOE scientists participating in a GRC COMPAS study that examined shielding requirements for a set of operational concepts (CONOPs). Based on these analyses a shielding architecture, consisting of three segments, was determined to provide the most versatile and weight-efficient option:

- An inverse wine-glass-type shield surrounds the reactor core. This segment minimizes radiation in the direction of the equipment and also minimizes dose contribution of ground reflection.

- A separate shielding enclosure will protect the electronic equipment. Exact size of this segment will be determined based on the location and size of the enclosure.

\footnotetext{
${ }^{9}$ Impact of the Use of Low or Medium Enriched Uranium on the Masses of Space Nuclear Power Systems, United States Department of Energy, Office of Nuclear Energy (December 1994).
} 
- Finally, a snap-on "adjustable" directional shielding panels will augment shielding of human habitat.

Segmentation will minimize the amount of shielding required on the FSP Tech Demo (vs what could be added later as part of a human mission). Another important finding is that human access to the reactor equipment is possible within a day after the reactor is shutdown; which allows for limited preventive maintenance and recovery actions by humans if necessary.

Primarily depending on the number and size of the Stirling controllers and battery packs, weight of the shielding required to satisfy dose criteria at locations 1,2 and 3 would vary between $500 \mathrm{~kg}$ to $900 \mathrm{~kg}$ (600 kg is the 'recommended estimate'). Shielding weight is only weakly dependent on the reactor class or fuel choice (that is, all reactor classes resulted in approximately the same weight; fast-spectrum systems required slightly larger LiH neutron shield whereas moderated systems required a thicker depleted uranium or tungsten gamma shield. The weights of reactor classes inclusive of shielding, but not the balance-of-plant, are 900-1100 kg, 1450-1650 kg, 800$1200 \mathrm{~kg}$, and 900-1200 kg for HEU-Fast, LEU-Fast, LEU-YH and LEU-ZrH classes, respectively. Thus shielding by itself is not a discriminator, but when combined with reactor weight, it exacerbates weight concerns associated with LEU-Fast.

\subsection{Non-Nuclear Technology Readiness Level Sensitivity to Reactor Class}

All four design classes require non-nuclear technology maturation of selected systems, including:

- methods for bonding/welding of heat pipes to the core block or core plates;

- shutdown and start-up control system inclusive of nuclear sensors and stepper motors;

- neutron and gamma shield that can withstand launch loads;

- high-performance multi-layer insulation required to prevent heat losses from the core;

- core, reflector, and shield decay heat management systems; and

- a myriad of sensors and structures required for mission assurance and monitoring.

On the Advancement Degree of Difficulty $\left(\mathrm{AD}^{2}\right)$ scale, none of the technology maturation tasks associated with the reactor systems, structures, and components exceeded a rating higher than 4; they all fall within the qualitative ratings of "well understood and certain to succeed". Activities envisioned to mature these technologies are well within the experience base of DOE laboratories and selected industry partners. Non-nuclear technology readiness is not a discriminator among the design classes.

\subsection{Nuclear Technology Readiness Level Sensitivity to Reactor Class}

HEU-Fast and LEU-Fast classes are inherently self-regulating. Their thermal power output varies to deliver electric demand without needing external controls or human intervention. A proof-ofprinciple nuclear demonstration of this concept - including its ability to self-regulate - was recently demonstrated at the temperature and power levels of interest to FSP. This test provided prototypical data to validate computational tools to be used for FSP design. Combined with U.S. NRC accepted Code Scalability Applicability and Uncertainty (CSAU) approach, it is possible to qualify fast-spectrum reactors with a high degree of confidence without additional nuclear demonstration. 
The governing mechanics behind self-regulation are dictated by thermal feedbacks or density changes in the fast systems. When a moderator is introduced, neutron speeds are no longer just fast, they exist in a range of speeds (or energies). As the energy of the neutron decreases, the probability of it causing fission increases. This associated probability distribution is very well known yet not completely linear and introduces an additional complexity to the mechanisms governing the self-regulation feedbacks. Computational tools that simulate this phenomena exist and have been in use for decades. But they have not been validated at FSP temperature range or for the specific FSP material combinations. For this reason, the moderated designs classes (LEU$\mathrm{YH}$ and LEU-ZrH) will require a nuclear test, as was done for the fast systems, to confirm selfregulation. Such a test will provide validation of computational tools.

Nuclear Technology Readiness Level - in terms of need for conducting a prototype nuclear demonstration - is a major discriminator among the design classes. However, this level should be assessed as part of the overall nuclear demonstration needs discussed below. If NASA risk-based acceptance policy requires a long-duration ground nuclear demonstration of qual-unit (as was the case in case of SNAP), then nuclear demonstration is not a discriminator. On the other hand, if FSP project is structured such that NRC's CSAU or NNSA's Quantification of Margins and Uncertainty or NE's Quantification of Uncertainty (QU) can be used to eliminate the need for a full-scale nuclear demonstration, then nuclear demonstration is not necessary for HEU-Fast and LEU-Fast classes. It would be still needed for LEU-YH and LEU-ZrH. In the case of LEU-ZrH demonstration is expected to be confirmative in nature and therefore of short-duration. LEU-YH may need a more extensive nuclear demonstration.

\section{PEER REVIEW FINDINGS}

An independent peer review was completed by experts outside this project. Focus of their review was to answer the following questions:

- Are presented technologies and development pathway aligned for a 2027 launch?

- Do the TRL, MRL and $\mathrm{AD}^{2}$ assessments seem reasonable?

- Are additional key analyses needed to validate the feasibility of the classes?

- Does the Technology Maturation path seem plausible? 
Important findings and/or recommendations by the peer review team are that:

- The TRLs and MRLs presented by the FSP team seem reasonable and consistent with NASA numerical rankings

- The four design classes reasonably envelope trade options. All four designs are feasible and no major apparent barriers would prohibit them from being developed from preconceptual design to demonstration.

- Although, the benefits, challenge, TRL, and associated $\mathrm{AD}^{2}$ to overcome the challenges and mature each design varied, no one reactor design was significantly better than the other ones. LEU-Fast seems to challenge NASA's weight requirements.

- Establishing moderator viability for this mission is important for many ongoing projects. Preferably, hydrogen retention in the moderators must be addressed through additional non-nuclear testing covering the operating envelope and off-set conditions before decisions related to fuel down-select.

A separate report documents the peer-review findings.

\section{CONCLUSIONS}

An analysis of alternative reactor classes, comprising of different fuel, moderator, and reflector options, was carried out to assess feasibility of NASA's Fission Surface Power Capability Demonstration Mission with a launch date of 2027. An important focus of this analysis was to identify and evaluate applicable designs, materials and technologies that have strong heritage and align well with the U.S. commercial microreactor industry's technology and manufacture base. Findings of the study, including component and system technology readiness levels, were peer reviewed by independent nuclear reactor experts as required by the STMD guidelines.

Heritage space reactor designs were simple (see Figure 1) comprising of few traditional nuclear components and relied heavily on inherent ability of the reactors to self-regulate. While the designs themselves are extensible to FSP, many of the components have to be reengineered and qualified to support current mission which is more demanding (see Table 1). For example, to support higher power conversion efficiency, FSP reactor is required to operate at a slightly higher temperature compared to heritage designs; similarly, its structure is required to withstand not only launch loads but also landing loads; and finally, its control system is required to support 15-year multiple on/off/load-following duty cycles at a reliability consistent with human mission ${ }^{10}$. Therefore, exact replication of heritage fuels, materials and technologies will not be sufficient to meet FSP requirements. A development program is required to mature and qualify selected reactor parts as presented in Table 3. Rapid maturation and testing of risk-significant components is necessary not only to achieving target TRL value of 6 by Preliminary Review but also to aid the fuel/reactor down-select process. In particular, as recommended by the peer review team, moderator lifetesting and qualification should be pursued as soon as possible to develop a viable thermal

\footnotetext{
${ }^{10}$ While capability demonstration itself is nominally a one-year mission, it is to serve as gateway to future longduration missions.
} 
spectrum system design that is deployable by the desired date or before it is ruled out as viable. Commercial microreactor vendors and other federal agencies are facing similar dilemma, namely moderators are vital for economic viability but they are not qualified for long-term use at higher temperatures. It is in this regard that FSP can be of benefit to and benefit from ongoing commercial microreactor industry efforts. Leveraging this synergy, FSP program could develop a significant number of components, such as moderator, reflector and control software, jointly with the industry and turn over final fabrication to the industry thus minimizing the need to establish dedicated federal infrastructure. In return, nuclear qualification data from the DOE laboratory testing program - which is an acknowledged gap in the industry capabilities - could be shared with the industry to further their readiness levels for future space and DOD missions. Such a joint development program is already underway between DOE laboratories and the industry; as an early adapter FSP can benefit and assure that development aligns with FSP long-term plans.

Beyond development needs identified in Table 3, FSP program requires facilities and expertise for assembling, engineering, nuclear testing and demonstration of the overall reactor system. To examine feasibility and assess infrastructure readiness four classes of reactors, namely HEU-Fast, LEU-Fast, LEU-YH and LEU-ZrH, were formulated. These classes sufficiently envelope heritage and current microreactor vendor interests. Table 4 provides insights gained from this assessment including relative merits (drawbacks) of each design class, and the readiness of existing DOE facilities, validated computational tools, and expertise that was required to mature, fabricate and demonstrate each reactor class was assessed. No major apparent barriers would prohibit them from being developed from pre-conceptual design to demonstration, and DOE possesses necessary infrastructure and technology base. If long-term ground testing is required then a dedicated facility may have to be commissioned; a more detailed assessment will be needed once scope of groundtesting is established. 


\section{Table 1. Technical Design Requirements}

\begin{tabular}{|c|c|}
\hline & Moon \\
\hline Power Levels & 7-10 kWe (40-60 kWt) \\
\hline Launch Dates & 2027 \\
\hline $\begin{array}{l}\text { Operating Environment } \\
\text { Temperature Extremes }\end{array}$ & $\begin{array}{l}\text { Lunar day ( } 375 \mathrm{~K} \text { TBR) or permanently shadow crater } \\
(40 \mathrm{~K}-50 \mathrm{~K} \text { TBR) }\end{array}$ \\
\hline Reactor Temperature & $925-1050 \mathrm{~K}$ \\
\hline $\begin{array}{l}\text { Static Gravitational Acceleration at } \\
\text { Destination, } g\end{array}$ & $0-1.62 \mathrm{~m} / \mathrm{s}^{2}$ \\
\hline Fission Power System Mass & Optimize based on general shielding requirements \\
\hline Dynamic Payload Diameter ${ }^{\ddagger}$ & Minimize (TBR) \\
\hline Dynamic Payload Length ${ }^{\ddagger}$ & Minimize (TBR) \\
\hline Design Life & $\begin{array}{l}\text { Capability Demonstration Mission }=1 \text { year } \\
\text { Follow-on mission }=>15 \text { years }\end{array}$ \\
\hline Operation Time & 365 Earth days (12 lunar day/night cycles (1 year) \\
\hline Cycles (on/off) & Up to $10 /$ year \\
\hline Radiation Tolerance Humans & $\begin{array}{l}5 \mathrm{rem} / \mathrm{yr} \text {-direction to the habitat at no less than } 1 \mathrm{~km} \\
\text { (TBR) distance from the habitat; negotiated to } 3 \\
\mathrm{mrem} / \mathrm{hr} \text { taking into consideration factors such as } \\
\text { occupancy (total time to which an astronaut is exposed } \\
\text { to radiation) and potential for radiation knockdown by } \\
\text { natural landscape. }\end{array}$ \\
\hline $\begin{array}{l}\text { Dose to Onboard Components } \\
\text { (Stirling Convertors, Control } \\
\text { Motors, End Users, etc.) }\end{array}$ & $\begin{array}{l}5.0 \mathrm{e} 14 \text { neutron } / \mathrm{cm}^{2}(>100 \mathrm{keV}) \\
10 \mathrm{MRad}(\operatorname{Rad} \mathrm{Si})\end{array}$ \\
\hline Dose to External Electronics & $\begin{array}{l}1.0 \mathrm{e} 12 \text { neutrons } / \mathrm{cm}^{2}(>100 \mathrm{keV}) \\
100 \mathrm{kRad}(\mathrm{Rad} \mathrm{Si}) \\
\text { Distance to FPS electronics: } \geq 100 \mathrm{~m}(\mathrm{TBR})\end{array}$ \\
\hline Load Bus & $120 \mathrm{Vdc}$ \\
\hline Launch Loads & See Appendix C for worst cases \\
\hline Landing Loads & 4 g's (TBR) \\
\hline Other Consideration & Vacuum, Dust, and Regolith \\
\hline
\end{tabular}




\section{Table 2. STMD Guidelines for FSP Development}

1. A reactor TRL assessment, established by an independent group, and a technology maturation plan for a 10kWe system per NASA NPR 7123.1B and NPR 7120.5E.

2. A system mass sensitivity analysis, relative to the $2000 \mathrm{~kg}$ mass target, comparing reactor fuel options over the 7-10 kWe power range of interest.

3. A preliminary concept of how the system would be packaged on the lander and how the radiator would be deployed for operation (if needed), including stowed and deployed dimensions and approximate c.g. location.

4. A radiation dose versus distance sensitivity analysis for sensitive electronics and potential human habitats on the Moon and Mars for a range of distances of $2 \mathrm{~m}$ to $1000 \mathrm{~m}$ from the reactor source.

5. Supporting documentation (testing, analysis) of the core's maximum lifetime in years at full power operation or total kWh of electrical power.

6. Analysis of the load-following characteristics of the core, including an explanation on how the core supports steady state and transient behavior for an acceptably wide variation of dynamic effects.

7. U.S. policies and strategies for processing and launching a space reactor, including nonproliferation and potential launch risks.

8. Hardware heritage description for any existing technology considered as part of the concept designs.

9. CAD models for the FPS concept designs.

10. FPS full system mass; considering mass growth allowance following ANSI/AIAA S-120A2015 Standard, Mass Properties Control for Space Systems.

11. Estimated development cost for the FPS including any technology maturation phase; qualification and Assembly, Test, Launch, Operations (ATLO).

12. Estimated FPS development schedule (risk informed) from Approval to Proceed (ATP) to Launch Date (please see Table I).

13. Development and programmatic risks that may affect both cost and schedule.

14. Full qualification and acceptance test plan for the fission power system including any 18 infrastructure requirements and needs 


\section{Table 3. Readiness Levels of Selected FSP Components and Materials.}

\begin{tabular}{|c|c|c|c|c|}
\hline Component & $\begin{array}{l}\text { Functional } \\
\text { Requirement }\end{array}$ & Make / Buy & TRL & Notes \\
\hline Nuclear Fuel (3.1) & $\begin{array}{l}\text { Sustained fission } \\
\text { generates heat in the } \\
\text { fuel. Thermal creep, } \\
\text { fission gas release and } \\
\text { swelling are known } \\
\text { challenges }\end{array}$ & $\begin{array}{l}\text { Procure parts. Process } \\
\text { development needed } \\
\text { for assembly and } \\
\text { qualification }\end{array}$ & $4-5$ & $\begin{array}{l}\text { UMo, UN and AGR TRISO nuclear fuel are qualified for FSP burnup and } \\
\text { temperature conditions. UMo and UN have been breadboard tested in } \\
\text { vacuum; UN was the fuel for SP-100. AGR TRISO has not been } \\
\text { breadboarded for vacuum and space conditions. } \\
\text { Tasks to be done to reach TRL 6: } \\
\text { Thermal bonding process optimization required for minimizing } \Delta T \\
\text { across the "gap". } \\
\text { Core structural design and assessment for launch/landing loads. } \\
\text { Scaled system demonstration in a relevant environment }\end{array}$ \\
\hline $\begin{array}{l}\text { Moderator block or } \\
\text { plates (3.2) }\end{array}$ & $\begin{array}{l}\text { Slow down neutrons to } \\
\text { increase core reactivity }\end{array}$ & 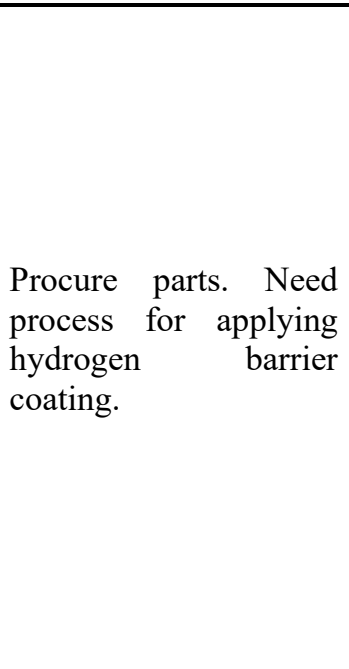 & $3-4$ & $\begin{array}{l}\mathrm{ZrH} \text { Moderators used in heritage systems (SNAP and TOPAZ). Tested as } \\
\text { part of NERVA. ZrH moderator has good irradiation and cross section data. } \\
\text { YH moderator used in FFTF and nuclear aircraft program, but needs } \\
\text { additional cross-section and irradiation data. } \\
\text { Tasks to be done to reach TRL 6: } \\
\text { a) Irradiation testing of } \mathrm{YH} \text { at planned hydrogen loadings } \\
\text { b) Process development and qualification of cladding and barrier } \\
\text { coatings. LEU-YH requires unique barrier to retain } \mathrm{H}_{2} \text { at } 800 \mathrm{C} \text {. LEU- } \\
\mathrm{ZrH} \text { requires FeCrAl steel coated with } \mathrm{Al}_{2} \mathrm{O}_{3} \text { or other clad/coat } \\
\text { technologies } \\
\text { c) Thermal bonding process optimization required for minimizing } \Delta \mathrm{T} \\
\text { across the "gap". } \\
\text { d) Structural assessment for launch loads } \\
\text { e) Scaled system demonstration in a relevant environment (vacuum and } \\
\text { launch loads) }\end{array}$ \\
\hline Reflector (3.3) & $\begin{array}{l}\text { Minimize leakage of } \\
\text { neutrons. He build up } \\
\text { and conductivity } \\
\text { degradation are known } \\
\text { challenges }\end{array}$ & Procure/ Assemble & 5 & $\begin{array}{l}\text { Be and Beo routinely used in test reactors. TRL and } \mathrm{AD}^{2} \text { values from } \\
\text { Materion and Peragrine. Vendors prefer full assembly contract and } \\
\text { acceptance criteria. } 2 \text { years of lead time if parts are 'Nuclear QA'. } \\
\text { Tasks to be done to reach TRL 6: } \\
\text { a) Structural assessment for launch loads and prototype testing }\end{array}$ \\
\hline
\end{tabular}




\begin{tabular}{|c|c|c|c|c|}
\hline Component & $\begin{array}{l}\text { Functional } \\
\text { Requirement }\end{array}$ & Make / Buy & TRL & Notes \\
\hline $\begin{array}{l}\text { Neutron and Gamma } \\
\text { Shield (3.4) }\end{array}$ & $\begin{array}{l}\text { Shield electronics, } \\
\text { humans from neutron } \\
\text { flux }\end{array}$ & Procure/ Assemble & 5 & $\begin{array}{l}\text { LiH in 316L cladding shielding is used by other federal programs. Enriched } \\
{ }^{6} \mathrm{Li} \text { isotope available per DOE process. } \\
\text { Tasks to be done to reach TRL 6: } \\
\text { a) Structural assessment for launch loads and prototype testing } \\
\text { b) Shield cooling to be engineered and integrated with radiator system } \\
\text { c) Explore alternative shields to minimize mass }\end{array}$ \\
\hline $\begin{array}{l}\text { Core Can and } \\
\text { Structure (3.5) }\end{array}$ & $\begin{array}{l}\text { SS Outer Can to } \\
\text { protect core during } \\
\text { transport \& assembly }\end{array}$ & Procure & 6 & $\begin{array}{l}\text { FSP specs for composition and tolerance within industry experience base. } \\
\text { Tasks to be done to reach TRL 6: } \\
\text { a) Structural assessment for launch loads and scaled prototype testing }\end{array}$ \\
\hline $\begin{array}{lr}\text { CRD } & \text { Drive } \\
\text { including } & \text { stepper } \\
\text { motors, } & \text { sensors, } \\
\text { controllers, } & \text { and } \\
\text { software (3.6) } & \end{array}$ & $\begin{array}{l}\text { Provide movement of } \\
\text { CRD in the radiation } \\
\text { and heat environment. } \\
\text { Software should make } \\
\text { it possible for active } \\
\text { control during startup } \\
\text { to compensate H2 } \\
\text { reconfiguration }\end{array}$ & Procure/Test/Assemble & 3 & $\begin{array}{l}\text { SNAP and SP-100 drawings and data exist for CRD systems. Considerable } \\
\text { plant experience. Major risks are vacuum environment, 15-year duty cycle } \\
\text { and remote operation; qualification required. } \\
\text { Tasks to be done to reach TRL 6: } \\
\text { a) Bushings and motor to be designed, tested and qualified to withstand } \\
\quad \text { vacuum. } \\
\text { b) Software and hardware miniaturization and space qualification } \\
\text { c) Space qualification of neutron, temperature and position sensors } \\
\text { d) Breadboard and scaled prototype testing }\end{array}$ \\
\hline $\begin{array}{l}\text { Heat Transfer } \\
\text { Technologies (3.7) }\end{array}$ & $\begin{array}{l}\text { Thermal transport of } \\
\text { core heat to PCS }\end{array}$ & Make or procure & 6 & $\begin{array}{l}\text { Gas turbine and heat pipe options exist. Heat pipe has higher TRL. Two } \\
\text { vendors possess capability to build gas circulation system; none beyond } \\
\text { TRL of } 2 \text {. } \\
\text { Tasks to be done to reach TRL 6: } \\
\text { a) Procure and long-term accelerated testing }\end{array}$ \\
\hline Insulation (3.8) & $\begin{array}{l}\text { Keep moderator cool } \\
\text { and prevent thermal } \\
\text { losses }\end{array}$ & Procure & 3 & $\begin{array}{l}\text { MLI insulation is routinely used in all high temperature testing/furnaces } \\
\text { Tasks to be done to reach TRL 6: } \\
\text { a) Extend GPHS qualification with neutron irradiation } \\
\text { b) Space qualification for the reactor loads } \\
\text { c) c) Breadboard and scaled prototype testing }\end{array}$ \\
\hline
\end{tabular}




\begin{tabular}{|c|c|c|c|c|}
\hline & HEU-Fast & LEU-Fast & LEU-YH & LEU-ZrH \\
\hline $\begin{array}{l}\text { Reactor } \\
\text { Design Class } \\
\text { (Basis) }\end{array}$ & \multicolumn{2}{|c|}{$\begin{array}{l}\text { Purpose: Explore simplest reactor options in fast spectrum. A } \\
\text { cylindrical shell of uranium-( } 8 \% \text { ) molybdenum alloy (U8Mo) } \\
\text { surrounded by BeO reflector forms the core. HEU-Fast Fuel is } \\
>90 \% \text { enriched in }{ }^{235} \mathrm{U} \text {. LEU-Fast fuel is } 19.75 \% \text { enriched in }{ }^{235} \mathrm{U} \\
\text { (HALEU). Heritage: BUK Reactors of Soviet era and KRUSTY } \\
\text { test }\end{array}$} & $\begin{array}{l}\text { Purpose: Explore neutronically } \\
\text { and thermally homogenous } \\
\text { moderated design for FSP. } \\
\text { Yttrium Hydride, a higher } \\
\text { temperature moderator, is used. } \\
\text { Because YH is reactive with } \\
\text { uranium, fuel is separated from } \\
\text { the moderator using a buffer } \\
\text { layer. Heritage: SNAP Reactor. }\end{array}$ & $\begin{array}{l}\text { Purpose: Explore options for using high } \\
\text { TRL ZrH within its qualification range. } \\
\text { Moderator block is thermally insulated } \\
\text { from the fuel and maintained at } 400- \\
500 \text { C to eliminate potential for } \\
\text { hydrogen loss. Ongoing NTP R\&D. } \\
\text { Heritage: Peewee and TOPAZ (US). }\end{array}$ \\
\hline $\begin{array}{l}\text { Auxiliary } \\
\text { components } \\
\text { (Mass basis) }\end{array}$ & \multicolumn{4}{|c|}{$\begin{array}{l}\text { Common to all designs: } \mathrm{A} \mathrm{B}_{4} \mathrm{C} \text { central shutdown rod acts as thermostat and operated using stepper motors. No active controls for load } \\
\text { following. Sodium heat pipes for heat removal (eliminate the need for liquid metal electro-magnetic pump which is heavy and requires } \\
\text { between } 2-5 \mathrm{kWe} \text { ). } 50 \% \text { redundancy. Tungsten, and LiH provide gamma shielding. Steel for structural support. }\end{array}$} \\
\hline $\begin{array}{l}\text { Mass } \\
\text { (Target } \leq 2000 \\
\mathrm{~kg} \mathrm{w} / \mathrm{pcs})\end{array}$ & $\begin{array}{l}\text { Lowest mass at } 10 \mathrm{kWe} \text { case; } \\
\text { estimated to be } 1000 \mathrm{~kg} \\
\text { including shielding. Likely to } \\
\text { meet mass limit (w/PCS) }\end{array}$ & $\begin{array}{l}\text { Heaviest mass at } 10 \mathrm{kWe} \text {; } \\
\text { mass including shielding is } \\
1600 \mathrm{~kg} \text {. Unlikely to meet } \\
\text { mass limit (w/ PCS) }\end{array}$ & \multicolumn{2}{|c|}{$\begin{array}{l}\text { Cores of moderated systems are approximately } 10-20 \% \text { heavier than the } \\
\text { HEU Design. With shield they weigh around } 1100 \mathrm{~kg} \text {. Likely to meet mass } \\
\text { limit. Future spirals, especially at higher power levels, are likely to be very } \\
\text { competitive relative to the HEU Fast alternate. }\end{array}$} \\
\hline $\begin{array}{l}\text { Technology } \\
\text { readiness } \\
\text { Non-Nuclear }\end{array}$ & \multicolumn{4}{|c|}{$\begin{array}{l}\text { Present TRL is below the target value of 6; it varies between } 3 \text { and } 5 \text { depending on reactor classes. List of development tasks includes (i) } \\
\text { designing, testing and qualifying central shutdown rod mechanism; (ii) thermal and mechanical bonding of heat pipes to the core; (iii) } \\
\text { designing, space qualification and fabrication of neutron and gamma shield; (iv) designing, qualification and fabrication of multi-layer } \\
\text { insulation; and (v) overall space, vacuum qualification of the assembly. A complete list of development tasks discussed in Table } 3 \text {. }\end{array}$} \\
\hline $\begin{array}{l}\text { Technology } \\
\text { readiness } \\
\text { nuclear } \\
\text { components }\end{array}$ & \multicolumn{2}{|c|}{$\begin{array}{l}\text { TRL of } 5 . \text { Breadboarding and Heritage. Simple physics. } \\
\text { Reactor performance technology and performance proven in } \\
\text { recent physics tests. Nuclear data available for validating } \\
\text { computation design tools. Likely to meet } 2027 \text { launch date } \\
\text { with risks pending on outcome of several development tasks. }\end{array}$} & $\begin{array}{l}\text { TRL of } 3 ; \text { Requires nuclear } \\
\text { experiments first to optimize the } \\
\text { design and a demonstration to } \\
\text { confirm performance. Possible to } \\
\text { meet } 2027 \text { launch but possesses } \\
\text { high schedule risk. }\end{array}$ & $\begin{array}{l}\text { TRL of } 4 \text { because analogous designs } \\
\text { were previously nuclear and/or vacuum } \\
\text { tested. Rapid maturation via non- } \\
\text { nuclear testing followed by a nuclear } \\
\text { confirmatory demonstration. Likely to } \\
\text { meet } 2027 \text { launch with schedule risk. }\end{array}$ \\
\hline
\end{tabular}




\begin{tabular}{|c|c|c|c|c|}
\hline & HEU-Fast & LEU-Fast & LEU-YH & LEU-ZrH \\
\hline $\begin{array}{l}\text { Industry } \\
\text { alignment }\end{array}$ & $\begin{array}{l}\text { Requires DOE facilities for } \\
\text { HEU. Limited industry } \\
\text { interest. }\end{array}$ & $\begin{array}{l}\text { At least two U.S. companies } \\
\text { have analogous designs in } \\
\text { multi-MW range. U.S. NRC } \\
\text { review underway. Another } \\
\text { company has an AM version } \\
\text { with } \mathrm{UO}_{2} \text { at } \mathrm{MW} \text { scale. }\end{array}$ & $\begin{array}{l}\text { At least one U.S. company has an } \\
\text { analogous design and an R\&D } \\
\text { program. The design is at the } \\
\text { same power range ( } 1-10 \mathrm{kWe}) \text {. }\end{array}$ & $\begin{array}{l}\text { Concept shares similarities with several } \\
\text { vendors designs }- \text { albeit at higher } \\
\text { power levels }(1-10 \text { MWe). Similar } \\
\text { concepts for Nuclear Thermal } \\
\text { Propulsion. Good alignment with } \\
\text { industry R\&D but not the design/fuel. }\end{array}$ \\
\hline $\begin{array}{l}\text { Extensibility to } \\
\text { higher powers } \\
\text { and missions }\end{array}$ & $\begin{array}{l}\text { Can be scaled up to } \\
\text { efficiently deliver up to } 100 \\
\text { kWe. Most advantageous at } \\
\text { lower powers ( } 1 \mathrm{KWe}) \text {. Could } \\
\text { be useful in bridging gap } \\
\text { between RPS and Fission } \\
\text { power. }\end{array}$ & $\begin{array}{l}\text { Power levels of } 1-2 \mathrm{MW} \text { th are } \\
\text { achievable. Use of ceramic } \\
\text { fuels }\left(\mathrm{UO}_{2}, \mathrm{UN}, \mathrm{UC}\right) \text { would be } \\
\text { needed at higher powers. } \\
\text { Ceramic fuels increase mass } \\
\text { by a factor of } 2 \text { in certain } \\
\text { power range. }\end{array}$ & $\begin{array}{l}\text { Design particularly suitable for } \\
\text { low powers } \quad<100 \mathrm{kWe}) \\
\text { Extremely difficult to scale up or } \\
\text { down without significant mass } \\
\text { penalty. }\end{array}$ & $\begin{array}{l}\text { Concept is best for scaling up to higher } \\
\text { powers. It is also flexible in fuel use. } \\
\text { Using traditional ceramic fuels instead } \\
\text { of UMo increases weight by } 25 \% \text {. Use of } \\
\text { TRISO possible. Concept could not be } \\
\text { scaled down without mass penalty }\end{array}$ \\
\hline
\end{tabular}

Table 4: Important Trade-offs between alternate reactor classes (Contd.). 
